\title{
Physicochemical and sensory characteristics of fat-free goat milk yogurt with added stabilizers and skim milk powder fortification
}

\author{
F. P. Bruzantin, ${ }^{*}$ J. L. P. Daniel, † P. P. M. da Silva, ${ }^{*}$ and M. H. F. Spoto*1 \\ *Department of Agri-Food Industry, Food and Nutrition, University of São Paulo, "Luiz de Queiroz" College of Agriculture, 13418-900, Piracicaba, \\ SP, Brazil \\ †Department of Animal Science, State University of Maringá, 87020-900, Maringá, PR, Brazil
}

\begin{abstract}
Goat milk yogurt has a less consistent coagulum compared with cow milk yogurt; furthermore, the presence of goat milk in foodstuffs imparts a characteristic flavor that can restrict its acceptance by consumers. This study aimed to assess and compare the physicochemical and sensory characteristics of fat-free goat milk yogurts with added stabilizers or bovine skim milk powder to improve the final product. Four treatment additions were evaluated: (1) a mixture of $0.1 \%$ (wt/vol) carrageenan and $0.1 \%$ (wt/vol) pectin (treatment CR); (2) $0.5 \%$ (wt/vol) pectin (treatment PE); (3) 4.65\% (wt/vol) bovine skim milk powder (treatment BM); and (4) control (no stabilizer; treatment CT). The physicochemical parameters were investigated at on $\mathrm{d} 1$ and 5 of storage. The $\mathrm{BM}$ treatment presented higher $\mathrm{pH}$ and titratable acidity values, resulting in a buffering capacity effect. The total crude protein (CP) and solids-not-fat (SNF) contents were also higher in BM compared with the other evaluated treatments because of the addition of bovine skim milk powder. We detected a reduction in $\mathrm{pH}$ values for all treatments. Lower SNF contents were present in the $\mathrm{CR}$ and $\mathrm{CT}$ treatments, which might be related to a syneresis process during storage; moreover, an increase in total CP was observed for all treatments due to the proteolytic action of the starter culture. Sensory attributes, including appearance (color, consistency, and presence of lumps), texture (consistency, viscosity, and presence of lumps), flavor (bitter, sweet, and characteristic of commercial plain nonfat yogurt), and overall impression were evaluated by quantitative descriptive analysis. The addition of $0.5 \%$ (wt/vol) of pectin (PE treatment) strengthened the curd; however, the visual and oral presence of lumps and a higher bitterness score were noted by trained panelists, which resulted in the lowest overall impression score for the PE treatment. In several sensory attributes, the CR
\end{abstract}

Received August 28, 2015.

Accepted January 24, 2016.

${ }^{1}$ Corresponding author: martaspoto@usp.br treatment was considered similar to the control; the mixture of $0.1 \%$ (wt/vol) carrageenan and $0.1 \%$ (wt/ vol) pectin was not as effective as expected. Goat milk yogurt containing added bovine skim milk powder (BM) had improved consistency, viscosity, and flavor due to its higher SNF and total CP contents, which are particularly important for the desirable texture of plain nonfat yogurt. In addition, the BM yogurt was considered to have characteristics most similar to that of available commercial brands and achieved the best score for overall impression.

Key words: skim milk powder, carrageenan, pectin, quantitative descriptive analysis, principal component analysis

\section{INTRODUCTION}

The economic contribution and nutritional value of goat milk can be observed in developing countries, particularly in the Mediterranean region, the Middle East, Eastern Europe, and South America (Ribeiro and Ribeiro, 2010). In Brazil, there is increasing demand for new dairy products with high added value in sophisticated market niches, which has stimulated goat milk production and trade (Fonseca et al., 2013).

Goat milk is highly digestible and can be consumed by people with cow milk allergies and gastrointestinal disorders; therefore, it can be used as a healthy substitute for cow milk products (Haenlein, 2004; Mituniewicz-Malek et al., 2014). Because of its chemical composition, goat milk has only a low level of, or lacks, $\alpha \mathrm{s}_{1}$-casein, which affects formation of an almost semiliquid coagulum (Seelee et al., 2009); moreover, the intense flavor of goat milk restricts acceptance of its derivatives by consumers (Gomes et al., 2013). Therefore, consistency and texture can be improved by adding dried milk solids and stabilizers (Wang et al., 2012; Mituniewicz-Malek et al., 2014). More research and technology are required for characterization of dairy products made with goat milk (Sant'Ana et al., 2013).

The production of reduced-fat products is a priority for the food industry; however, fat in food has a 
great effect on appearance, flavor, and texture, and it influences customer acceptance of dairy products (Tomaschunas et al., 2012). Fat-free and low-fat yogurts are soft, have a low solids content, and exhibit whey separation unless they are heavily stabilized (Trachoo and Mistry, 1998).

In this study, we investigated the use of stabilizers, including carrageenan and pectin, and milk fortification. In dairy products, carrageenan interacts with casein at $\mathrm{pH} 6.7$ in normal milk and at the isoelectric point ( $\mathrm{pH} 4.6$ ) of casein. Above the isoelectric point, polyvalent metallic ions in solution form bridges of protein negatively charged carboxylic groups and negative charges from carrageenan sulfate ester groups (Lin, 1977; Moirano, 1977; Glicksman, 1982; Whistler and Daniel, 1985; Syrbe et al., 1998). Pectin is a polysaccharide derived from plant cell walls; it forms gels with casein micelles and calcium after acidification by milk fermentation (Endress et al., 2005; Wang et al., 2012). Milk base fortification is one of the most important steps that enhances functional and nutritional properties and prevents textural defects such as poor gel firmness and syneresis in yogurts. The SNF content is traditionally increased to achieve a protein concentration between 40 and $50 \mathrm{~g} / \mathrm{kg}$ (Karam et al., 2013). The rate of skim milk powder (SMP) addition to a yogurt mix ranges from 1 to $6 \%$, but the recommended level is 3 to $4 \%$ (Tamime and Robinson, 2007). Thomopoulos et al. (1993) obtained low-fat milk yogurts with higher solids contents, which significantly increased apparent viscosity. Seelee et al. (2009) observed an improvement in viscosity and smoothness of goat milk yogurt after addition of concentrated whey protein to a final concentration of $3 \%$ (wt/vol).

In this study, we aimed to evaluate the physicochemical and sensory characteristics of fat-free goat milk yogurt with added stabilizers and SMP fortification.

\section{MATERIALS AND METHODS}

\section{Yogurt Preparation}

Eight liters of goat milk was provided by the Animal Science Department and plain fat-free yogurt was produced in the Dairy Laboratory facilities at "Luiz de Queiroz" College of Agriculture, Piracicaba, São Paulo, Brazil. After the cream fraction of the milk was removed, the remainder was divided equally into 4 beakers and treated as follows: (1) a mixture of $0.1 \%$ (wt/vol) carrageenan (Seakem GP 418, FMC Química do Brasil, Campinas, Brazil) and $0.1 \%$ (wt/vol) pectin (treatment CR); (2) $0.5 \%$ (wt/vol) pectin (low methoxyl, type 8002, CP Kelco do Brasil S.A., Limeira, Brazil; treatment PE); (3) 4.65\% (wt/vol) bovine SMP (adjustment of solids to $14 \% \pm 0.5$; treatment BM); and (4) control (no stabilizer; treatment CT). The beakers were placed into a water bath at $80^{\circ} \mathrm{C}$ for 30 min with constant stirring. The samples were cooled to $42^{\circ} \mathrm{C}$ and inoculated with $3 \%$ reactivated starter culture (Streptococcus salivarius ssp. thermophilus and Lactobacillus delbrueckii ssp. bulgaricus; Chr. Hansen Ind. e Com, Valinhos, Brazil). Inoculated samples were maintained at $42^{\circ} \mathrm{C}$ for $3 \mathrm{~h}$ until the $\mathrm{pH}$ reached 4.6 and then the incubation was stopped. The resulting yogurts were cooled and then stored at $4^{\circ} \mathrm{C}$.

\section{Physicochemical Analysis}

Specific gravity at $15^{\circ} \mathrm{C}$ (Brazil Ministry of Agriculture and Livestock, 1981), pH (method 981.12), titratable acidity (method 947.05), SNF (method 990.21), total $\mathrm{CP}(\mathrm{N} \times 6.38$, Kjeldahl method; method 991.20), and ash (method 945.46) contents of raw goat milk were analyzed by the methods recommended by AOAC International (2003). Total fat content was determined according to Newlander and Atherton (1964). All measurements were done in triplicate on the day the samples were collected.

The yogurts were analyzed for SNF, total CP, titratable acidity, and $\mathrm{pH}$ according to AOAC International (2003). Yogurt samples were collected in triplicate on d 1 and 5 of storage.

\section{Sensory Analysis}

The sensory analysis was established by using quantitative descriptive analysis (QDA; Stone et al., 1974; Meilgaard et al., 2007). This technique is commonly used in the evaluation of processed food, such as dairy products (Gaze et al., 2015). The panelists were recruited from master's degree students and laboratory technicians from Agri-Food Industry, Food and Nutrition Department of "Luiz de Queiroz," College of Agriculture, Brazil, and they were selected based on regular consumption of yogurt and time availability. The sensory evaluation process was conducted in individual booths under controlled lighting and temperature. Booths included potable water, styrofoam trays where the samples were served monadically, pencil, evaluation forms, eraser, and paper napkin. In the selection stage, the panelists were asked to recognize basic tastes of the following compounds and level of concentration: (a) sweet $[0.14 \%$ (wt/vol) sucrose $]$, (b) acid $[0.07 \%$ (wt/vol) citric acid], (c) salty $[0.5 \%$ (wt/ vol) sodium chloride], and (d) bitter $[0.07 \%(\mathrm{wt} / \mathrm{vol})$ caffeine] (Fisher and Yates, 1971). No assessors were excluded because all attained $100 \%$ accuracy. The flavor sensibility evaluation was carried out with 9 triangle 
tests ( 4 sessions of $3 \mathrm{~h}$ each) to check differences among the goat milk yogurt samples (with carrageenan and pectin and without stabilizers) and cow milk yogurt (Stone et al., 1974). Yogurts (30 g) were scooped into disposable plastic cups $(50 \mathrm{~mL})$ with random 3-digit codes. The panel selection results were performed considering the application of sequence analysis (Wald, 1947; Steiner, 1966; Dutcosky, 1996) considering the following probability values: $P_{0}=1 / 3 ; P_{1}=2 / 3 ; \alpha=$ 0.05 and $\beta=0.10$, where $P_{0}=$ maximum acceptable ability; $\alpha=$ probability to reject an acceptable panelist; and $P_{1}=$ minimum acceptable ability. Ten panelists $(3$ males and 7 females, aged 20-40 yr) were selected for the training stage.

During the session training, the sensory attributes were collected using the network method and generated in consensus across 3 sessions of $2 \mathrm{~h}$, in which the panelists tasted all treatments offered in pairs and were asked to identify the similarities and differences among them (Moskowitz, 1983). In later sessions, these attributes were grouped into one term based on similarity, and different attributes were removed. A meeting with panelists was conducted to define the final list as well as their references of weak and strong intensity. The lexicon generated for yogurts included 5 flavor, 5 appearance, 3 texture, and 1 overall impression. The descriptors (attributes), definitions, and reference samples developed by the sensory panel are shown in Table 1. The evaluation sheet consisted of a 9-cm unstructured scale and the lines had anchor descriptors at $0.5 \mathrm{~cm}$ from the ends, in which the left anchor represented the lowest intensity. The descriptive analysis of 4 treatments performed by the trained panel was carried out in 5 sessions lasting $2 \mathrm{~h}$ each, where each panelist evaluated each treatment in each section, using the evaluation sheet developed during the training session; each panelist received a small chocolate bar as compensation.

\section{Statistical Analysis}

Physicochemical data were submitted to statistical analysis as randomized complete blocks arranged in a 4 $\times 2$ factorial scheme (4 treatments: CR, PE, BM, and

Table 1. Descriptive terms for appearance, texture and flavor attributes and their reference materials used during the training of panelists and evaluation of goat milk yogurts

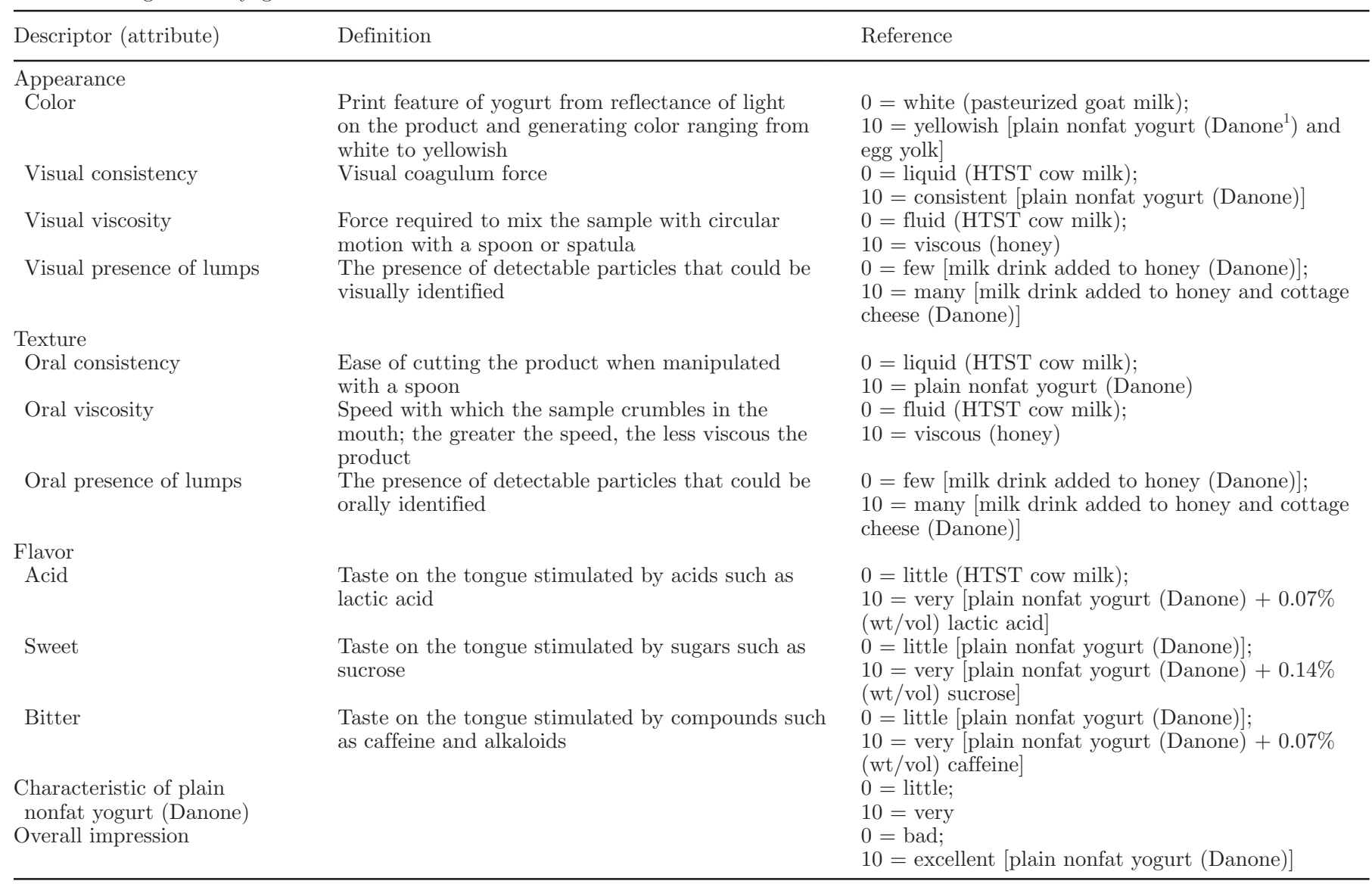

\footnotetext{
${ }^{1}$ Danone Brasil, Poços de Caldas, Brazil.
} 
CT; and 2 lengths of storage time: 1 and $5 \mathrm{~d}$ ), with each combination constituting 1 block, in a total of 5 randomized complete blocks.

Sensory analysis data were submitted to an experimental design by randomized complete blocks with each panelist constituting 1 block in a total of 10 blocks, considering only 1 factor with the 4 treatments.

The results were subjected to one-way ANOVA and means were compared by Tukey test, with statistically significant difference set at $P \leq 0.05$. In addition, the sensorial data were submitted to a multivariate analysis by principal component analysis (PCA), which resulted in a biplot. The PCA was used for characterization and to establish the relationship between treatments and attributes. Data were organized in the form of a $4 \times 10$ matrix (treatments $\times$ attributes). Each row corresponded to a goat milk yogurt treatment (CR, PE, $\mathrm{BM}$, and $\mathrm{CT}$ ), and each column referred to average scores of 10 yogurt attributes (color, visual consistency, visual presence of lumps, oral consistency, oral viscosity, oral presence of lumps, bitter taste, sweet taste, characteristic of commercial plain nonfat yogurt, and overall impression). All statistical analyses used SAS software (SAS Institute, 2005).

\section{RESULTS AND DISCUSSION}

\section{Gross Composition of Skim Milk}

The average composition of the pasteurized skim goat milk used to prepare the yogurts is given in Table 2. Because of the characteristic odor of goat milk, the cream was removed before preparation of yogurts. The odor might be partly related to the fatty acid composition of milk, which contains a higher proportion of medium-chain fatty acids, including caproic (C6:0), caprylic (C8:0), and capric (C10:0) fatty acids, released during the milking procedure (Jandal, 1996; Silanikove et al., 2010). Additionally, Chilliard et al. (2003) suggested a relationship between fatty acid composition and lipolytic system or even rancidity; therefore, a bond would form more easily between the lipoprotein lipase enzyme and goat milk fat globules, resulting in more spontaneous lipolysis.

Table 2. Average composition $( \pm \mathrm{SD})$ of pasteurized goat skim milk

\begin{tabular}{lc}
\hline Item & Value \\
\hline $\mathrm{pH}$ & $6.66 \pm 0.04$ \\
Titratable acidity $(\mathrm{g} / 100 \mathrm{~g}$ of lactic acid $)$ & $0.182 \pm 0.007$ \\
$\mathrm{SNF}(\mathrm{g} / 100 \mathrm{~g})$ & $9.45 \pm 0.31$ \\
Total CP $(\mathrm{g} / 100 \mathrm{~g})$ & $3.40 \pm 0.11$ \\
Ash $(\mathrm{g} / 100 \mathrm{~g})$ & $0.912 \pm 0.180$ \\
Specific gravity at $15^{\circ} \mathrm{C}\left(\mathrm{g} / \mathrm{cm}^{3}\right)$ & $1.034 \pm 0.001$ \\
\hline
\end{tabular}

Total acidity and $\mathrm{pH}$ have important roles in lactose fermentation and acceptability, as well as in the shelf life of yogurt (Kavas et al., 2003). In this study, the $\mathrm{pH}$ and lactic acid scores for titratable acidity (Table 2 ) were in agreement with the values in the literature: $\mathrm{pH} 6.3$ to 6.8 and 0.14 to $0.23 \mathrm{~g} / 100 \mathrm{~g}$ of lactic acid, respectively. Ash content (Table 2) was slightly higher compared with that of other published reports, 0.61 to $0.84 \mathrm{~g} / 100 \mathrm{~g}$, whereas specific gravity at $15^{\circ} \mathrm{C}$ was in agreement with the literature values, 1.0280 to 1.0390 $\mathrm{g} / \mathrm{cm}^{3}$ (Pandya and Ghodke, 2007; Park et al., 2007; Eissa et al., 2010; Costa et al., 2014b).

The main purpose of the increase in milk TS used to produce goat milk yogurt is to preserve the structure and texture of the final product. When TS content is increased, the intensity of the attractive forces between the casein micelles decreases, increasing the waterholding capacity and decreasing gel shrinkage, porosity, and natural syneresis (Kavas et al., 2003; Gomes et al., 2013). The SNF values (Table 2) were slightly higher compared with values in the literature: 8.06 to 9.12 g/100 g (Pandya and Ghodke, 2007; Park et al., 2007; Eissa et al., 2010; Costa et al., 2014b). Total protein content is also an important parameter related to acid gel formation. In goat milk, there are different $\alpha_{\mathrm{S} 1^{-}}$ $\mathrm{CN}$ genotypes that can be related to the total casein content and $\alpha_{\mathrm{S}_{1}-} \mathrm{CN}$ excretion. Some of these variants (low $\alpha_{\mathrm{S} 1}-\mathrm{CN}$ level) are characterized by larger micelles, which might be related to the lack of phosphoserine residues located on the surface of micelles, and interfere in the coagulation process. In its native state, most of the casein is usually bound to the calcium phosphate via their serine phosphate residues to produce a crosslinked network (Tziboula and Horne, 1999). In addition, $\mathrm{pH}$, low calcium content, and genetic polymorphism of goat milk protein may be related to poor coagulation properties (Vegarud et al., 1999). The total CP value (Table 2) was in agreement with the range (3.15-3.60 $\mathrm{g} / 100 \mathrm{~g}$ ) in the literature (Pandya and Ghodke, 2007; Park et al., 2007; Costa et al., 2014b).

The nutrient composition of goat milk can be influenced by several factors, including season, stage of lactation, breed, diet, individual animal, and environmental management conditions (Haenlein, 2004).

\section{Physicochemical Properties of Goat Milk Yogurts}

The $\mathrm{pH}$ value, total $\mathrm{CP}$ content, and SNF content were affected by treatment and by storage period, whereas titratable acidity was affected only by treatment. We detected a significant interaction between treatment and storage period for SNF content.

Treatments CR, PE, and CT exhibited a significant decrease in $\mathrm{pH}$ during storage, whereas the $\mathrm{pH}$ of the 
BM treatment remained the same. The titratable acidity parameter demonstrated no significant difference across the storage period for the $\mathrm{PE}, \mathrm{BM}$, and $\mathrm{CT}$ treatments. For treatment BM, there was no change in $\mathrm{pH}$ or titratable acidity because of the increased TS content, which might result in a modification of the $\mathrm{pH}$-acidity relationship due to the buffering capacity of compounds, including proteins, phosphates, citrates, and lactates, during storage. The $\mathrm{pH}$ values (Table 3 ) were in agreement with the range of 4.15 to 4.50 in the literature (Kavas et al., 2003; Matos et al., 2013). The titratable acidity, however, was slightly higher in our study (range $=1.03-1.36 \mathrm{~g} / 100 \mathrm{~g}$ of lactic acid) than the values previously reported by Kavas et al. (2003; $0.69-0.85 \mathrm{~g} / 100 \mathrm{~g}$ of acid lactic). This discrepancy might be related to the action of the starter cultures that hydrolyze lactose into lactic acid during the fermentation process. Acidification rate of yogurts (fortified and nonfortified) can be influenced by many factors, including growth characteristics, specific growth rate, fermentation time, sugar or amino acid consumption, and product yields (Marafon et al., 2011; Wang et al., 2012).

Total CP was increased for all treatments after storage for $5 \mathrm{~d}$, in agreement with the literature (Kavas et al., 2003; Eissa et al., 2010); however, only the CR and PE treatments showed significant differences. According to Tamime and Robinson (1985), yogurt has an increased nitrogen content and a different profile of nitrogen compounds compared with milk because of the proteolytic action by Streptococcus salivarius ssp. thermophilus and Lactobacillus delbrueckii ssp. bulgaricus during fermentation and, to some extent, during storage. Total $\mathrm{CP}$ was greater in treatment $\mathrm{BM}$ and differed significantly $(P \leq 0.05)$ from the other treatments, because of the fortification of milk with SMP.
Total CP values of treatments CR, PE, and CT (Table 3 ) were lower compared with values in the literature, which ranged from 3.40 to $4.52 \mathrm{~g} / 100 \mathrm{~g}$ (Kavas et al., 2003; Wang et al., 2012).

Eissa et al. (2010) reported SNF values ranging from 8.79 to $9.09 \mathrm{~g} / 100 \mathrm{~g}$, which was slightly higher compared with treatments CR, PE, and CT (Table 3). Moreover, the SNF value was reduced after $5 \mathrm{~d}$ of storage to values similar to those of treatments $\mathrm{CR}$ and $\mathrm{CT}$. The reason might be related to a syneresis process involving low SNF content, cream removal, low acidity, and so on; the same condition was not observed for treatments PE or BM (Tamime and Robinson, 1985).

\section{Sensory Analysis}

Several methods are currently used to characterize the sensory properties of food products such as the repeated-exposure method, check-all-that-apply, projective mapping, sorting, intensity scales, and QDA (Cruz et al., 2013; Costa et al., 2014a). The QDA is a well-established, consistent, and robust sensory method performed by a well-trained panel (Cruz et al., 2013); therefore, it was the best option to achieve our purpose.

Yogurts from the 4 treatments were analyzed for sensory attributes, including appearance (color, visual consistency and visual presence of lumps); texture (oral consistency, oral viscosity, and oral presence of lumps); flavor (bitter, sweet and characteristic of plain nonfat commercial yogurt), and overall impression (Table 4).

The color was stronger and tended toward yellowish for treatments $\mathrm{PE}$ and $\mathrm{BM}$ compared with $\mathrm{CR}$ and $\mathrm{CT}$. In this study, pectin was extracted from orange, which is an important and complex source of carotenoids, one of the main classes of natural pigments localized in the peel and pulp of different citrus fruits (Melendez-

Table 3. Physicochemical composition of goat milk yogurts submitted to different treatments during storage

\begin{tabular}{|c|c|c|c|c|c|c|}
\hline \multirow[b]{2}{*}{ Item } & \multirow{2}{*}{$\begin{array}{l}\text { Storage } \\
\text { (d) }\end{array}$} & \multicolumn{4}{|c|}{ Treatment $^{1}$} & \multirow[b]{2}{*}{ SEM } \\
\hline & & $\mathrm{CR}$ & $\mathrm{PE}$ & $\mathrm{BM}$ & $\mathrm{CT}$ & \\
\hline \multirow[t]{2}{*}{$\overline{\mathrm{pH}}$} & 1 & $4.21^{\mathrm{B}, \mathrm{a}}$ & $4.24^{\mathrm{B}, \mathrm{a}}$ & $4.32^{\mathrm{A}, \mathrm{a}}$ & $4.21^{\mathrm{B}, \mathrm{a}}$ & 0.0079 \\
\hline & 5 & $4.17^{\mathrm{B}, \mathrm{b}}$ & $4.19^{\mathrm{B}, \mathrm{b}}$ & $4.31^{\mathrm{A}, \mathrm{a}}$ & $4.19^{\mathrm{B}, \mathrm{b}}$ & 0.0079 \\
\hline \multirow{2}{*}{ Titratable acidity $(\mathrm{g} / 100 \mathrm{~g})$} & 1 & $1.15^{\mathrm{B}, \mathrm{a}}$ & $1.03^{\mathrm{C}, \mathrm{a}}$ & $1.35^{\mathrm{A}, \mathrm{a}}$ & $1.10^{\mathrm{B}, \mathrm{a}}$ & 0.0164 \\
\hline & 5 & $1.06^{\mathrm{B}, \mathrm{b}}$ & $1.09^{\mathrm{B}, \mathrm{a}}$ & $1.36^{\mathrm{A}, \mathrm{a}}$ & $1.04^{\mathrm{B}, \mathrm{a}}$ & 0.0164 \\
\hline \multirow[t]{2}{*}{ Total CP (g/100 g) } & 1 & $2.90^{\mathrm{B}, \mathrm{a}}$ & $2.90^{\mathrm{B}, \mathrm{a}}$ & $5.23^{\mathrm{A}, \mathrm{a}}$ & $2.79^{\mathrm{B}, \mathrm{a}}$ & 0.0370 \\
\hline & 5 & $3.15^{\mathrm{BC}, \mathrm{b}}$ & $3.31^{\mathrm{B}, \mathrm{b}}$ & $5.32^{\mathrm{A}, \mathrm{a}}$ & $2.90^{\mathrm{C}, \mathrm{a}}$ & 0.0363 \\
\hline \multirow{2}{*}{$\operatorname{SNF}(g / 100 g)$} & 1 & $8.55^{\mathrm{C}, \mathrm{a}}$ & $7.81^{\mathrm{D}, \mathrm{a}}$ & $14.10^{\mathrm{A}, \mathrm{a}}$ & $8.62^{\mathrm{B}, \mathrm{a}}$ & 0.1469 \\
\hline & 5 & $7.32^{\mathrm{C}, \mathrm{b}}$ & $7.98^{\mathrm{B}, \mathrm{b}}$ & $14.20^{\mathrm{A}, \mathrm{a}}$ & $7.20^{\mathrm{D}, \mathrm{b}}$ & 0.1469 \\
\hline
\end{tabular}

$\overline{\mathrm{a}, \mathrm{b}}$ Mean values within a variable (d 1 vs. 5 ) with the same lowercase superscript letters are not significantly different from each other $(P>0.05)$.

${ }^{\mathrm{A}-\mathrm{D}}$ Mean values within a row with the same uppercase superscript letters are not significantly different from each other $(P>0.05)$.

${ }^{1}$ Treatments: $\mathrm{CR}=$ mixture of $0.1 \%(\mathrm{wt} / \mathrm{vol})$ carrageenan and $0.1 \%(\mathrm{wt} / \mathrm{vol})$ pectin; $\mathrm{PE}=0.5 \%(\mathrm{wt} / \mathrm{vol})$ pectin; $\mathrm{BM}=4.65 \%$ (wt/vol) bovine skim milk powder; $\mathrm{CT}=$ control (no stabilizer). 
Martinez et al., 2007; Fratianni et al., 2010). Likewise, SMP contains carotene, which gives a more yellowish color to cow milk compared with goat milk, which contains no carotenoids (Jandal, 1996). Goat milk has a greater amount of vitamin A compared with cow milk and because goats convert all $\beta$-carotene into vitamin A in the milk, caprine milk is whiter than bovine milk (Park et al., 2007).

According to the sensory analysis results, the structure of goat milk yogurt was changed by treatments $\mathrm{PE}$ and $\mathrm{BM}$ compared with the control, which was smoother and more friable, reflecting the protein composition (Park et al., 2007; Seelee et al., 2009; Costa et al., 2014b). Goat milk yogurt after treatment with PE or BM had high scores for visual and oral consistency and oral viscosity compared with $\mathrm{CR}$ and $\mathrm{CT}$ treatments. According to the panelists, the BM was more similar to plain nonfat commercial yogurt, whereas the consistency of PE was more similar to that of a pudding or flan compared with the other yogurts evaluated. This change might have taken place after fermentation due to the action of lactic acid, which is responsible for casein becoming positively charged at $\mathrm{pH}<4$.6. At the same time, negatively charged pectin interacts with casein and calcium ions, increasing the stability of the protein gel, which provides the enhanced firmness and creaminess of yogurt products as well as the mouthfeel of, specifically, low-calorie products (Endress et al., 2005). Basak and Ramaswamy (1994) recommended that the concentration of pectin should be in the range of 0.3 to $0.4 \%$ in cow milk yogurt without the addition of pulp fruit. Treatment PE had a more bitter taste and the visual presence of lumps, and it was judged by panelists to be the worst treatment with respect to the characteristics of plain nonfat commercial yogurt score. Moreover, the PE treatment was significantly $(P$ $\leq 0.05)$ different in visual presence of lumps compared with CR and CT; we detected no statistical differences in terms of bitter taste among the $\mathrm{PE}, \mathrm{CR}$, and $\mathrm{CT}$ treatments. The bitterness might be related to the flavor and aromatic compounds in orange juice, including aldehydes (hexanal, heptanal, octanal, citral), esters (ethyl butanoate, methyl hexanoate), and monoterpenes ( $\alpha$-pinene, D-limonene, linalool, $\alpha$-terpineol; Mastello et al., 2015). Pulp fruit can be added to mask the bitter taste but further studies are needed to identify other technological resources for improving the final product.

According to statistical results, goat milk yogurt containing added SMP (BM treatment) was characterized by its sweet taste and achieved the best scores for overall impression compared with commercial brands. Flavor and aroma are considered the most important parameters for consumer acceptance and the purchase decision for dairy products. For instance, goat milk yogurt presents higher contents of acetoin and ethanol but a lower content of acetaldehyde compared with milks of other origins (Gomes et al., 2013; Hassan et al., 2014). Treatment BM had a sweeter taste compared with the other treatments due to lactose hydrolysis during fermentation, resulting in an increase of free galactose (Toba et al., 1983; Tamime and Robinson, 1985). Becker and Puhan (1989) reported that the increased content of SNF (9-10.3\%) in milk added with skim milk powder showed a positive correlation with viscosity of stirred yogurt. The BM treatment received high scores for consistency (visual and oral), oral viscosity, and the visual presence of lumps. The structure of fermented milks is complex, although they contain high levels of moisture and the gel behaves like a solid-like material. This behavior is due to the aggregation of casein micelles in the milk and formation of a 3-dimensional network (Tamime and Robinson, 2007). The addition

Table 4. Sensory attributes and overall impression of goat milk yogurts submitted to different treatments

\begin{tabular}{|c|c|c|c|c|c|c|}
\hline \multirow[b]{2}{*}{ Property } & \multirow[b]{2}{*}{ Attribute $^{2}$} & \multicolumn{4}{|c|}{ Treatment $^{1}$} & \multirow[b]{2}{*}{ SEM } \\
\hline & & $\mathrm{CR}$ & $\mathrm{PE}$ & $\mathrm{BM}$ & $\mathrm{CT}$ & \\
\hline \multirow{2}{*}{ Appearance } & Visual consistency & $3.21^{\mathrm{C}}$ & $7.57^{\mathrm{A}}$ & $7.33^{\mathrm{A}}$ & $4.22^{\mathrm{B}}$ & 0.2652 \\
\hline & Visual presence of lumps & $3.66^{\mathrm{B}}$ & $5.37^{\mathrm{A}}$ & $5.04^{\mathrm{AB}}$ & $4.75^{\mathrm{B}}$ & 0.4020 \\
\hline \multirow[t]{2}{*}{ Texture } & Oral consistency & $2.65^{\mathrm{C}}$ & $7.64^{\mathrm{A}}$ & $6.89^{\mathrm{A}}$ & $3.87^{\mathrm{B}}$ & 0.2446 \\
\hline & Oral viscosity & $3.72^{\mathrm{B}}$ & $5.74^{\mathrm{A}}$ & $5.88^{\mathrm{A}}$ & $4.02^{\mathrm{B}}$ & 0.2864 \\
\hline \multirow{2}{*}{ Flavor } & Sweet taste & $2.49^{\mathrm{B}}$ & $2.39^{\mathrm{B}}$ & $3.80^{\mathrm{A}}$ & $2.63^{\mathrm{B}}$ & 0.2039 \\
\hline & Characteristic taste of plain nonfat commercial yogurt & $4.80^{\mathrm{B}}$ & $4.71^{\mathrm{B}}$ & $6.27^{\mathrm{A}}$ & $5.19^{\mathrm{B}}$ & 0.2893 \\
\hline Overall impression & & $5.30^{\mathrm{B}}$ & $4.83^{\mathrm{B}}$ & $6.68^{\mathrm{A}}$ & $5.51^{\mathrm{B}}$ & 0.2055 \\
\hline
\end{tabular}

\footnotetext{
${ }^{\mathrm{A}-\mathrm{C}}$ Mean values within a row with different superscripts differ $(P \leq 0.05)$.

${ }^{1}$ Treatments: $\mathrm{CR}=$ mixture of $0.1 \%$ (wt/vol) carrageenan and $0.1 \%(\mathrm{wt} / \mathrm{vol}$ ) pectin; $\mathrm{PE}=0.5 \%$ (wt $/ \mathrm{vol}) \mathrm{pectin} ; \mathrm{BM}=4.65 \%(\mathrm{wt} / \mathrm{vol}) \mathrm{bovine}$ skim milk powder; $\mathrm{CT}=$ control (no stabilizer).

${ }^{2}$ Score scales from 1 (lowest intensity) to 9 (highest intensity).
} 
of SMP resulted in increased milk protein content and, thus, it improved the texture of BM yogurt (Marafon et al., 2011). Kavas et al. (2003) reported the lowest whey-off values for a yogurt made from $50 \%$ (vol/vol) goat milk and $50 \%$ (wt/vol) cow milk powder because of the higher TS content. With respect to its sensory properties, the BM yogurt was considered the most attractive for industrial production. It is known that yogurt viscosity varies depending on the type of milk and is higher for milk with higher solids and protein contents. Tamime and Robinson (1985) found the best yogurt was produced with reconstituted milk of 15 to $16 \%$ TS; commercial yogurts contain 14 to $15 \%$ TS.

Scanning electron microscopy, for examining the microstructure of goat milk yogurt, shows that a relatively more comprehensive network is formed when polymerized whey protein is added to yogurt, resulting in improved consistency and water-holding capacity of the goat milk yogurt (Wang et al., 2012). Marafon et al. (2011) found that the microstructure of all yogurt samples (fortified with whey protein concentrate, SMP, and sodium caseinate, as well as nonfortified) was composed of casein micelles linked to each other slightly differently. The resulting matrices appeared relatively more compact (denser) in the fortified product after storage for $1 \mathrm{~d}$, which could be due to the fortified product containing more protein. Mistry and Hassan (1992) reported that an increase in the protein content of yogurt reduces the porosity of structure produced from skim milk, providing firmness and minimal whey separation to the final product.

Principal component analysis was used as an auxiliary tool to support the sensory characterization of goat milk yogurts due to the examination of correlations between sensory attributes and treatments; PCA is one of the most commonly used methods to reduce the dimensionality of the original data set into a few new variables and it shows trends as well as outliers (Aquino et al., 2014; Goyeneche et al., 2014; Matera et al., 2014). Moreover, PCA allows the projection of these points on 2-dimensional graphs with minimal geometric distortion so that inter-sample similarities and differences can be assessed (Spoto et al., 1997). The number of principal components to be used depends on the proportion of total variance that must be accumulated by $70 \%$ or more (Larrigaudiere et al., 2004).

Treatment CR did not improve the appearance and texture attributes of goat milk yogurts (Table 4); therefore, neither CR nor CT was included in the discussion of PCA results.

In this study, Figure 1 shows the projection of variables and treatments. Two principal components explaining $90.4 \%$ of the total variance were obtained from the sensory analysis data set (Table 4). The first
(PC1) explained $55.6 \%$ of the variance and presented a positive correlation with color, visual consistency, and visual presence of lumps, oral consistency, and oral viscosity. The second (PC2) explained $34.8 \%$ of the variance and was correlated positively with bitter taste and negatively with sweet taste, characteristics of plain nonfat commercial yogurt taste, and overall impression.

The PE treatment presented oral and visual consistency, slightly yellowish color, visual presence of lumps, and oral viscosity, whereas it presented a low level of characteristics of plain nonfat commercial yogurt taste and a low score for overall impression. In addition, the PE treatment had slightly sweet taste and very bitter taste. The BM treatment was similar to PE in terms of appearance and texture attributes; however, because BM yogurt had very sweet taste and low bitter taste, it would be accepted by consumers. Treatment BM had characteristics of plain nonfat commercial yogurt taste and the highest score for overall impression.

\section{CONCLUSIONS}

According to the physicochemical properties of goat milk yogurts, the CR and PE treatments presented similar behavior after $5 \mathrm{~d}$ of storage. Higher values of $\mathrm{pH}$, titratable acidity, total $\mathrm{CP}$, and SNF were associated with the BM treatment due to the addition of bovine SMP. From the QDA and PCA results, treatment CR was not satisfactory for improving the quality of fat-free goat milk yogurt, considering that several attributes (color, visual presence of lumps, oral viscosity, bitter taste, sweet taste, characteristic taste of plain nonfat yogurt, and overall impression) had scores similar to the control yogurt (without stabilizers). In contrast, treatment PE achieved the highest score for oral consistency (texture attribute) but had more pronounced bitterness, as well as the oral presence of lumps, compared with the other treatments, so its sensory acceptability was compromised. Goat milk yogurt containing added bovine SMP obtained excellent scores for sensory attributes in terms of the characteristics of plain nonfat yogurt, visual and oral consistency, oral viscosity, sweet taste, and the lowest score for bitter taste. The BM treatment also achieved the best score for overall impression and was considered the best product among those evaluated. Goat milk and its derivatives are a viable option for the dairy market; however, further studies and technological development are required for manufacturing a fat-free goat milk yogurt.

\section{ACKNOWLEDGMENTS}

The authors are grateful to the financial support of Fundação de Amparo à Pesquisa do Estado de São 


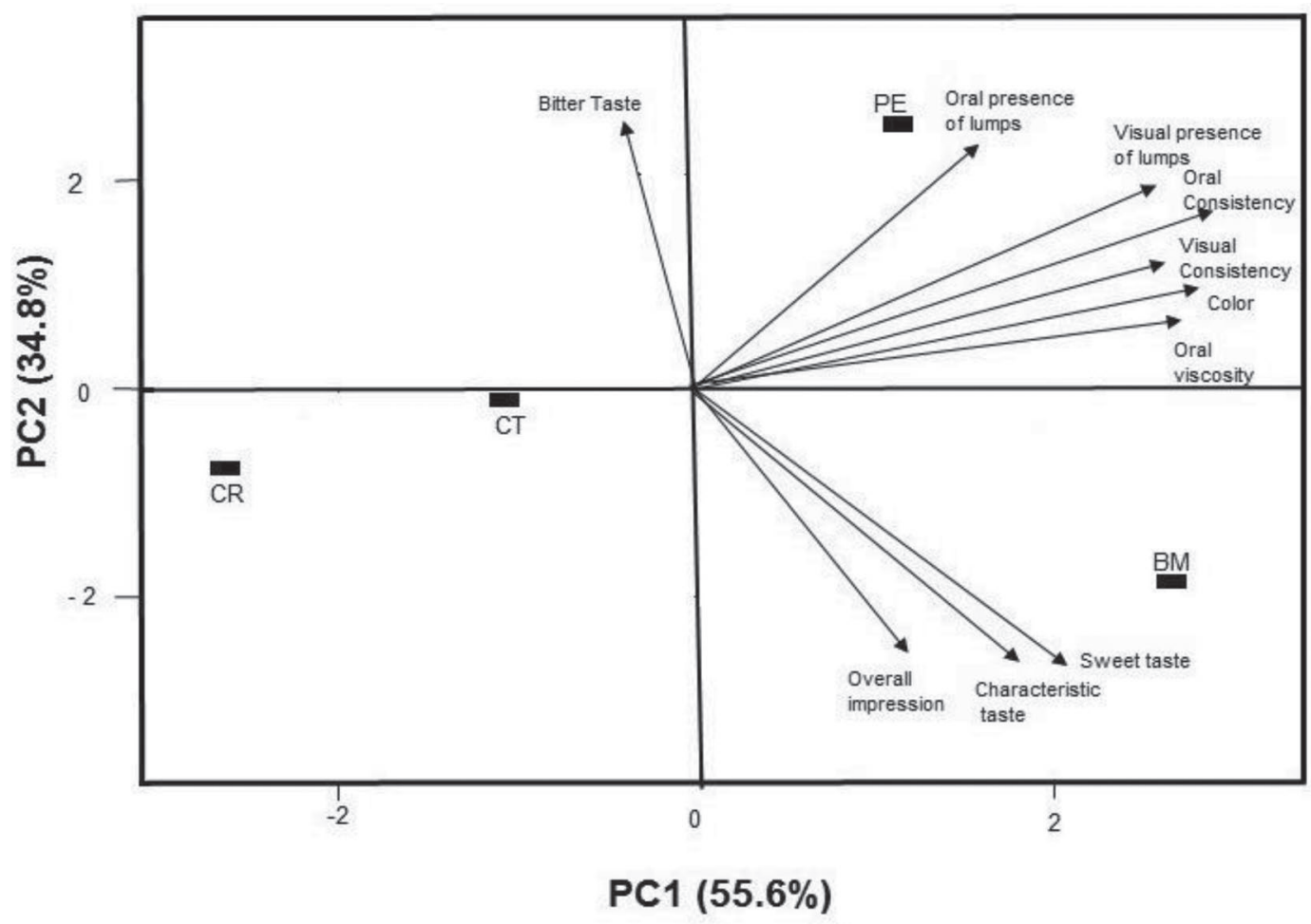

Figure 1. Principal component (PC) analysis of goat milk yogurts. Treatments: $\mathrm{CR}=$ mixture of $0.1 \%$ (wt/vol) carrageenan and $0.1 \%$ (wt/ vol) pectin; $\mathrm{PE}=0.5 \%$ (wt/vol) pectin; $\mathrm{BM}=4.65 \%$ (wt/vol) bovine skim milk powder; $\mathrm{CT}=$ control (no stabilizer).

Paulo (FAPESP, São Paulo, SP, Brazil) and Conselho Nacional de Desenvolvimento Científico e Tecnológico (CNPq, Brasília, Brazil) foundations.

\section{REFERENCES}

AOAC International. 2003. Official Methods of Analysis. 17th ed. AOAC International, Gaithersburg, MD.

Aquino, L. F. M. C., A. C. O. Silva, M. Q. Freitas, T. L. Felicio, A. G. Cruz, and C. A. Conte- Júnior. 2014. Identifying cheese whey an adulterant in milk: Limited contribution of a sensometric approach. Food Res. Int. 62:233-237.

Basak, S., and H. S. Ramaswamy. 1994. Simultaneous evaluation of shear rate and time dependency of stirred yogurt rheology as influenced by added pectin and strawberry concentrate. J. Food Eng. 21:385-393.

Becker, T., and Z. Puhan. 1989. Effect of different processes to increase the milk solids non-fat content on the rheological properties of yoghurt. Milchwissenschaft 44:626-629.

Brazil Ministry of Agriculture and Livestock. 1981. National Secretary of Agricultural Defense. National laboratory of animal reference. Ordinance no. 1, October 7th of 1981. Official analytical methods for the control of animal products and ingredients: Physicochemical methods. Official Diary of the Union, Brasilia, DF. [In Portuguese]

Chilliard, Y., A. Ferlay, J. Rouel, and G. Lamberet. 2003. A review of nutritional and physiological factors affecting goat milk lipid synthesis and lipolysis. J. Dairy Sci. 86:1751-1770.

Costa, M. P., C. F. Balthazar, R. M. Franco, E. T. Marsico, A. G. Cruz, and C. A. Conte-Júnior. 2014a. Changes in expected taste perception of probiotic and conventional yogurts made from goat milk after rapidly repeated exposure. J. Dairy Sci. 97:2610-2618.
Costa, W. K. A., E. L. Souza, E. M. Beltrão-Filho, G. K. V. Vasconcelos, T. Santi-Gadelha, C. A. A. Gadelha, O. L. Franco, R. C. R. E. Queiroga, and M. Magnani. 2014b. Comparative protein composition analysis of goat milk produced by the Alpine and Saanen breeds in northeastern Brazil and related antibacterial activities. PLoS ONE 9:e93361.

Cruz, A. G., R. S. Cadena, W. F. Castro, E. A. Esmerino, J. B. Rodrigues, L. Gaze, J. A. F. Faria, M. Q. Freitas, R. Deliza, and H. M. A. Bolini. 2013. Consumer perception of probiotic yogurt: Performance of check all that apply (CATA), projective mapping, sorting and intensity scale. Food Res. Int. 54:601-610.

Dutcosky, S. D. 1996. Sensory Analysis of Food. 1st ed. Champagnat, Curitiba, PR, Brazil.

Eissa, E. A., I. A. Mohamed-Ahmed, A. E. A. Yagoub, and E. E. Babiker. 2010. Physicochemical, microbiological and sensory characteristics of yoghurt produced from goat milk. Livest. Res. Rural Develop. 22:8-18.

Endress, H. U., F. Matter, and K. Norz. 2005. Pages 142-30 in Handbook of Food Science, Technology and Engineering. Vol. 4. Y. H. Hui and F. Sherkat, ed. CRC Press, Boca Raton, FL.

Fisher, R. A., and F. Yates. 1971. Statistical Tables for Biology, Agricultural and Medicine Research. University of São Paulo, São Paulo, SP, Brazil.

Fonseca, C. R., K. Bordin, A. M. Fernandes, C. E. C. Rodrigues, C. H. Corassin, A. G. Cruz, and C. A. F. de Oliveira. 2013. Storage of refrigerated raw goat milk affecting the quality of whole milk powder. J. Dairy Sci. 96:4716-4724.

Fratianni, A., L. Cinquanta, and G. Panfili. 2010. Degradation of carotenoids in orange juice during microwave heating. LWT Food Sci. Technol. (Campinas.) 43:867-871.

Gaze, L. V., B. R. Oliveira, L. L. Ferrao, D. Granato, R. N. Cavalcanti, C. A. Conte Júnior, A. G. Cruz, and M. Q. Freitas. 2015. Preference mapping of dulce de leche commercialized in Brazilian markets. J. Dairy Sci. 98:1443-1454. 
Glicksman, M. 1982. Food Hydrocolloids. 1st ed. CRC Press, Boca Raton, FL.

Gomes, J. J. L., A. M. Duarte, A. S. M. Batista, R. M. F. de Figueiredo, E. P. de Souza, E. L. de Souza, and R. de C. R. do E Queiroga. 2013. Physicochemical and sensory properties of fermented dairy beverages made with goat's milk, cow's milk and a mixture of two milks. LWT Food Sci. Technol. 54:18-24.

Goyeneche, R., S. Roura, and K. Di Scala. 2014. Principal component and hierarchical cluster analysis to select hurdle technologies for minimal processed radishes. LWT Food Sci. Technol. 57:522-529.

Haenlein, G. F. W. 2004. Goat milk in human nutrition. Small Rumin. Res. 51:155-163.

Hassan, F. A. M., H. M. Abbas, M. A. M. Abd El-Gawad, and A. K. Enab. 2014. Goat dairy products as potentially functional food. Life Sci. J. 11:648-657.

Jandal, J. M. 1996. Comparative aspects of goat and sheep milk. Small Rumin. Res. 22:177-185.

Karam, M. C., C. Gaiani, C. Hosri, J. Burgain, and J. Scher. 2013. Effects of dairy powders fortification on yogurt textural and sensory properties: A review. J. Dairy Res. 80:400-409.

Kavas, G., H. Uysal, S. Kiliç, N. Akbulut, and H. Kesenkas. 2003. Some properties of yoghurts produced from goat milk and cowgoat milk mixtures by different fortification methods. Pak. J. Biol. Sci. 6:1936-1939.

Larrigaudiere, C., I. Lentheric, J. Puy, and E. Pinto. 2004. Biochemical characterization of core browning and brown heart disorders in pear by multivariate analysis. Postharvest Biol. Technol. 31:29-39.

Lin, C. F. 1977. Interaction of sulfated polysaccharides with proteins. Pages 320-346 in Food Colloids. H. D. Graham, ed. AVI Publishing, Westport, CT

Marafon, A. P., A. Sumi, D. Granato, M. R. Alcantara, A. Y. Tamime, and M. N. de Oliveira. 2011. Effects of partially replacing skimmed milk powder with dairy ingredients on rheology, sensory profiling, and microstructure of probiotic stirred-type yogurt during cold storage. J. Dairy Sci. 94:5330-5340.

Mastello, R. B., M. Capobiango, S. T. Chin, M. Monteiro, and P. J. Marriott. 2015. Identification of odour-active compounds of pasteurised orange juice using multidimensional gas chromatography techniques. Food Res. Int. 75:281-288.

Matera, J. A., A. G. Cruz, R. S. L. Raices, M. C. Silva, L. C. Nogueira S. L. Quitério, R. N. Cavalcanti, M. Q. Freiras, and C. A. Conte Júnior. 2014. Discrimination of Brazilian artisanal and inspected pork sausages: Application of unsupervised, linear and non-linear supervised chemometric methods. Food Res. Int. 64:380-386.

Matos, S., A. Pinto, C. Castilho, P. R. Correia, and A. C. Monteiro. 2013. Mix goat and sheep yogurt: development and product characterization. Int. J. Biol. Vet. Agric. Food Eng. 7:301-304.

Meilgaard, M. C., G. V. Civille, and B. T. Carr. 2007. Sensory Evaluation Techniques. 4th ed. CRC Press, Boca Raton, FL.

Melendez-Martinez, A. J., I. M. Vicario, and F. J. Heredia. 2007. Review: Analysis of carotenoids in orange juice. J. Food Compos. Anal. 20:638-649.

Mistry, V. V., and H. N. Hassan. 1992. Manufacture of nonfat yogurt from a high milk protein powder. J. Dairy Sci. 75:947-957.

Mituniewicz-Malek, A., M. Ziarno, and I. Dmytrów. 2014. Incorporation of inulin and transglutaminase in fermented goat milk containing probiotic bacteria. J. Dairy Sci. 97:3332-3338.

Moirano, A. L. 1977. Sulfated seaweed polysaccharides. Pages 347-381 in Food Colloids. H. D. Graham, ed. AVI Publishing, Westport, $\mathrm{CT}$.

Moskowitz, H. R. 1983. Product Testing and Sensory Evaluation of Foods: Marketing and R\&D Approaches. Food and Nutrition Press Inc., Malden, MA.

Newlander, J. A., and H. V. Atherton. 1964. Babcock, Gerber, Mojonnier tests for fat. Pages $67-114$ in The Chemistry and Testing of Dairy Products. Olsen Publ., Milwaukee, WI.
Pandya, A. J., and K. M. Ghodke. 2007. Goat and sheep milk products other than cheeses and yoghurt. Small Rumin. Res. 68:193-206.

Park, Y. W., M. Juarez, M. Ramos, and G. F. W. Haenlein. 2007. Physico-chemical characteristics of goat and sheep milk. Small Rumin. Res. 68:88-113.

Ribeiro, A. C., and S. D. A. Ribeiro. 2010. Specialty products made from goat milk. Small Rumin. Res. 89:225-233.

Sant'Ana, A. M. S., F. F. Bezerril, M. S. Madruga, A. S. M. Batista, M. Magnani, E. L. Souza, and R. C. R. E. Queiroga. 2013. Nutritional and sensory characteristics of Minas fresh cheese made with goat milk, cow milk, or a mixture of both. J. Dairy Sci. 96:7442-7453.

SAS Institute. 2005. SAS/QC 9.2 User's Guide. SAS Inst. Inc., Cary, $\mathrm{NC}$

Seelee, W., W. Tungjaroenchai, and M. Natvaratat. 2009. Development of low fat set-type probiotic yoghurt from goat milk. Asian J. Food Agro-Indus. 2:771-779.

Silanikove, N.. G. Leitner, U. Merin, and C. G. Prosser. 2010. Recent advances in exploiting goat's milk: Quality, safety and production aspects. Small Rumin. Res. 89:110-124.

Spoto, M. H. F., R. E. Domarco, J. M. M. M. Walder, I. S. Scarminio, and R. E. Bruns. 1997. Sensory evaluation of orange juice concentrate as affected by irradiation and storage. J. Food Prot. 21:179-191.

Steiner, E. H. 1966. Sequential procedures for triangular tests and paired comparison tasting tests. J. Food Technol. 1:41-53.

Stone, H. J., S. Sidel, and A. Olivier. 1974. Sensory evaluation by quantitative descriptive analysis. Food Chem. 28:24-34.

Syrbe, A., W. J. Bauer, and H. Klostermeyer. 1998. Polymer science concepts in dairy system - an overview of milk protein and food hydrocolloid interaction. Int. Dairy J. 8:179-193.

Tamime, A. Y., and R. K. Robinson. 1985. Yoghurt: Science and Technology. 1st ed. Pergamon Press, Oxford, UK.

Tamime, A. Y., and R. K. Robinson. 2007. Yogurt: Science and Technology. 3rd ed. CRC Press, Boca Raton, FL.

Thomopoulos, C., C. Tzia, and D. Milkas. 1993. Influence of processing of solids-fortified milk on coagulation time and quality properties of yogurt. Milchwissenschaft 48:426-430.

Toba, T., A. Watanabe, and S. Adachi. 1983. Quantitative changes in sugars, especially oligosaccharides, during fermentation and storage yogurt. J. Dairy Sci. 66:17-20.

Tomaschunas, M., J. Hinrichs, E. Kohn, and M. Busch-Stockfisch 2012. Effects of casein-to-whey protein ratio, fat and protein content on sensory properties of stirred yoghurt. Int. Dairy J. 26:3135.

Trachoo, N., and V. V. Mistry. 1998. Application of ultrafiltered sweet buttermilk and sweet buttermilk powder in the manufacture of nonfat and low fat yoghurts. J. Dairy Sci. 81:3163-3171.

Tziboula, A., and D. S. Horne. 1999. The role of $\alpha_{\mathrm{S1}}$-casein in the structure of caprine casein micelles. Int. Dairy J. 9:173-178.

Vegarud, G. E., T. G. Devold, R. Opheim, E. Loeding, C. Svenning, R. K. Abrahamsen, S. Lien, and T. Langsrud. 1999. Genetic variants of Norwegian goat's milk composition, micellar size and renneting properties. Int. Dairy J. 9:367-368.

Wald, A. 1947. Sequential Analysis by Abraham Wald. John Wiley \& Sons Inc., New York, NY.

Wang, W., Y. Bao, G. M. Hendricks, and M. Guo. 2012. Consistency, microstructure and probiotic survivability of goat's milk yoghurt using polymerized whey protein as a co-thickening agent. Int Dairy J. 24:113-119.

Whistler, R. L., and J. R. Daniel. 1985. Carbohydrates. Pages 69-137 in Food Chemistry. Chapter 3. O. R. Fennema, ed. Marcel Dekker, New York, NY. 